\title{
Introducción a la concepción ecomunitarista de la TV en el socialismo del siglo XXI
}

Resumen: Mucho se ha escrito acerca de la estructura, funcionamiento y papel de los medios de comunicación (incluyendo a la TV) en la sociedad capitalista, desde perspectivas predominantemente filosóficas, sociológicas, psicológicas, económicas y/o técnicas. En este documento se pretende contribuir a delinear el perfil que debe tener la TV en la sociedad socialista del siglo XXI. Ahora bien, ello nos obliga a aclarar previamente nuestra concepción del socialismo del siglo XXI, del ecomunitarismo de la ética y del papel que los comunicadores están llamados a desempeñar en la nueva sociedad naciente.

Abstract: There are many writings about the structure, functioning and role of media (including TV) in capitalist society, from philosophical, sociological, psicological and/or technical perspectives. This paper pretends to be a contribution on the debate of the profile that TV must have in the socialist society of the $21^{\text {st }}$ century.

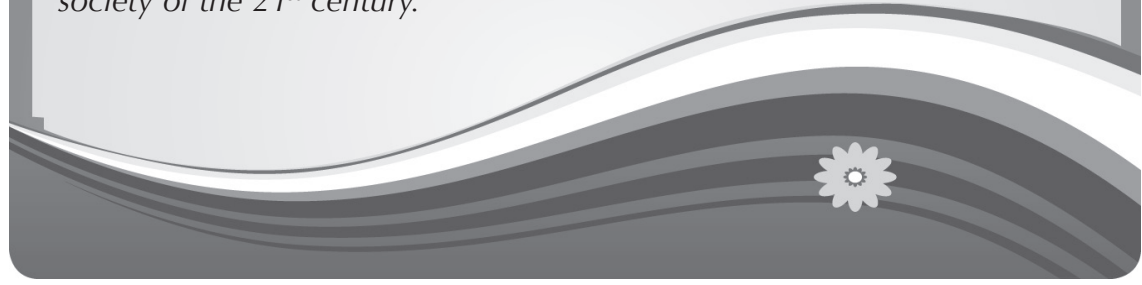

\section{Una píldora de ética y el ecomunitarismo}

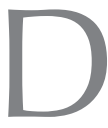
e las condiciones de "felicidad" (Austin 1962) de la pregunta que instaura la ética, a saber, "¿Qué debo hacer?", he deducido argumentativamente las tres normas éticas fundamentales, que nos exigen, respectivamente, bregar para realizar nuestra libertad individual de decisión, hacer efectiva esa libertad en procesos de 
búsquedas de acuerdos consensuales con los otros, y preservar-regenerar una naturaleza humana y no humana sana. (López Velasco 2009). Es a la luz de esas tres normas que hemos abordado todas las cuestiones relativas a la economía ecología y solidaria sin patrones, la política de todos, la educación ambiental problematizadora, la erótica de la liberación, (López Velasco 2010a, 20109b, y 2012) y también la comunicación simétrica, a la que prestaremos especial atención en este trabajo.

\section{El concepto del ecomunitarismo}

He definido el ecomunitarismo como el orden socioambiental utópico poscapitalista capaz de pautarse por las tres normas de la ética (que hemos deducido argumentativamente de la pregunta que la instaura y que nos obligan, respectivamente, a luchar por hacer realidad nuestra libertad individual de decisión, a realizarla consensualmente, y a preservar-regenerar una naturaleza humana y no humana sana). Ese orden utópico es un horizonte indispensable para orientar la acción diaria, y tomándolo como referencia, sopesar la significación de cada reforma y revolución. He definido el "poder" como la relación social que media entre los que deciden y los que no lo hacen, y he mostrado por un lado que el capitalismo niega la capacidad de decidir a cada individuo en el día a día, en especial a los asalariados y a los excluidos del trabajo (violando la primera norma de la ética), y, por otro, que la "revolución" consiste en ampliar dicha capacidad, bien por la ampliación del número de los que ya deciden (como sucede cuando la familia machista y patriarcal amplía el poder de decisión al conjunto de sus miembros, superando el monopolio ejercido por el pater familias), o por la sustitución de los que la ejercen (como sucedió en gran medida en Francia con la ascensión de la burguesía que desplazó a la aristocracia feudal en 1789 y los años siguientes, en la Rusia de 1917 y en la revolución cubana). Nuestro desafío es no infravalorar la primera alternativa, sin olvidarnos ni renunciar a la segunda. Por otro lado, la experiencia muestra que después de cualquier "revolución", se impone la necesidad diaria de "reformas", si no queremos que la revolución se petrifique. A propósito, esa es otra cara de la vieja discusión sobre la dialéctica revolución-reforma (que por lo menos desde Lenin dejó claro que ninguna reforma puede juzgarse individualmente, sino sobre el fondo del contexto que la caracteriza como revolucionaria o no). Creo que al filósofo del siglo XXI en América Latina no le cabe ni el papel del "hombre en la torre de cristal", alienado de la política, ni el papel del "intelectual orgánico" del marxismo-leninismo que subordina el filósofo al papel dirigente del Partido supuestamente de vanguardia. 
Una digresión: en momentos en que la clase obrera ha disminuido cuantitativamente y se ha modificado cualitativamente, con centrales sindicales que de hecho aceptan los límites del capitalismo, ya suena a museo la invocación de cualquier "partido obrero de vanguardia"; la tarea crítico-utópica ecomunitarista hoy es colocada en manos de un bloque social heterogéneo, con forma de movimiento, que agrupa a los asalariados, los excluidos de la economía capitalista formal, las llamadas "minorías" (que a veces son mayorías, como las mujeres, y algunas comunidades étnicas en algunos países), las minorías activas (sobre todo en movimientos, partidos, sindicatos y organizaciones no gubernamentales, y en especial muchas de carácter ambientalista), los pueblos indígenas que sin asumir una postura identitaria a-histórica esencialista, quieren permanecer $y$ transformarse sin aceptar el dogma de los "valores" capitalistas de la ganancia y del individualismo, y los movimientos de liberación nacional que combaten el recrudecido imperialismo yanqui-europeo.

Del ecomunitarismo, que pretende propiciar el libre y multifacético desarrollo de los individuos asociados solidariamente por decisión libre, hacen parte, resumidamente: a) una economía solidaria y ecológica basada en el principio que estipula "de cada uno según su capacidad y a cada uno según sus necesidades" y respetuosa de la norma ética que exige preservarregenerar una naturaleza humana y no humana sana pautada por los grandes equilibrios ecológicos, b) una pedagogía ambiental problematizadora (basada en Paulo Freire), de la que hace parte una educación sexual que fomenta el libre placer compartido y condena el machismo, el sexismo, y la culpabilización de la masturbación y de la homosexualidad, y c) una "política de todos" que fomenta la práctica de la democracia directa $y$, para las representaciones que se revelen indispensables, instrumenta la rotatividad de los representantes electos y revocables por sus electores en cualquier momento; esa política se propone la reconciliación solidaria de individuos y comunidades a nivel planetario, realizando la efectiva constitución del "género humano" como familia que (aunque atravesada por conflictos) resuelve los diferendos en provecho de todos y cada uno porque se ha pasado (como quería Marx) del gobierno de los hombres a la compartida administración de las cosas (velando por su "salud"; nótese que ese concepto va más allá de los organismos vivos, pues podemos postular que el aire que tenga más que una determinada cantidad de partículas en suspensión "no es saludable", para el ser humano en especial, o que la tierra que tenga más que un determinado nivel de salinización "no es saludable", en especial para la ganadería y agricultura, y/o que el agua que contenga más que una determinada 
cantidad de nutrientes nitrogenados o de agrotóxicos, "no es saludable", en especial para tomar o bañarse, o criar peces, etc.); e incluso podemos decir que no son "sanos" el agua, tierra o aire que hayan perdido (por ejemplo por contaminación) sus características físico-químicas originales, más allá de la relación de uso que el ser humano establezca con ellos.

\section{Brevísimo resumen de algunas de las características del socialismo del siglo XXI}

La propuesta del "socialismo del siglo XXI" surgió en la Venezuela bolivariana, $y$, como idea y realidad naciente, inacabada y en plena construcción, repercute principalmente en Ecuador y Bolivia, influyendo también en el aggiornamento del socialismo cubano y en los países del ALBA y de América Latina en general (alcanzando incluso dimensión mundial al inspirar a diversos movimientos revolucionarios o radical-reformistas que en Europa no ven futuro en el capitalismo, ni tan siquiera en su supuesta variante socialdemócrata). Intentaremos en lo que sigue resumir algunas características fundamentales de esta naciente propuesta-realidad.

\section{La satisfacción de las necesidades: rumbo al horizonte definido por el lema "de cada uno según sus capacidades y a cada uno según sus necesidades"}

Inspirándose en el eslogan "de cada uno según sus capacidades, y a cada uno según sus necesida-

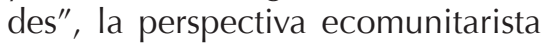
ha tenido el mérito de precisar qué debemos entender por "necesidades", aclarando que deben ser consideradas como tales todas aquellas demandas del desarrollo libre y multilateral de los individuos que no infrinjan ninguna de las tres normas éticas fundamentales (o sea, que no impidan la satisfacción de las necesidades ajenas y que no impliquen la violación de la obligación de preservar-regenerar una naturaleza humana y no humana sana, con lo que ello implica en lo relativo a la preservación de los grandes equilibrios ecológicos del planeta y de cada localidad).

Ahora bien, creo que es una semejanza marcante entre los socialismos de los siglos XX y XXI la reivindicación de la socialización de los medios de producción como única forma para que se puede avanzar en la aplicación del principio que reza "de cada uno según sus capacidades y a cada uno según sus necesidades"; claro que esa socialización no podrá ser más confundida (como sucedió en el socialismo real) con la simple estatización de esos medios; ahora, el socialismo del siglo XXI, 
por ejemplo en el caso venezolano, sin renunciar a la importancia de la "propiedad social indirecta" (donde el Estado ejerce la tutela en beneficio de todos), destaca la necesidad de edificar también la propiedad social directa, o sea aquella en la que la gestión está directamente confiada a los productores-distribuidoresconsumidores libremente asociados (en especial en los Consejos Comunales y las Comunas Socialistas). En una perspectiva ecomunitarista lo que defiendo es que la propiedad social indirecta a cargo del Estado debe rápida y continuamente transformarse en propiedad social directa (preservando mecanismos de coordinación-ayuda para que las comunidades sean mutuamente solidarias, en vista de satisfacer el eslogan antes mencionado); sin olvidarnos de que algunas áreas estratégicas (como la gestión de los hidrocarburos, mientras ellos sean utilizados, o la defensa nacional, deben mantenerse bajo coordinación centralizada, para bien de toda la nación, solidariamente constituida de sus partes).

Como se sabe, se ha clasificado los Derechos Humanos en diversas "dimensiones" (para no decir "generaciones" pues hay quienes discuten que haya habido una estratificación cronológica entre ellos, y en lo que sigue transcribimos casi integralmente el resumen hecho por Antonio Carlos Wolkmer ${ }^{1}$, desde los clásicos individuales y políticos; en la primera están los derechos civiles y políticos; se trata de los derechos individuales vinculados a la libertad, la igualdad, la propiedad, la seguridad y a la resistencia a las diversas formas de opresión (y son derechos inherentes a la individualidad, considerados atributos naturales, inalienables e imprescriptibles, que por ser de defensa y establecidos contra el Estado, tienen la especificidad de ser derechos "negativos"); luego están los derechos sociales, económicos y culturales, fundados en el principio de la igualdad y con cariz "positivo", pues cubren la garantía y concesión a todos los individuos de ciertos bienes por parte del poder público (entre ellos se destacan los derechos al trabajo, a la alimentación, a la salud, a la vivienda y a la educación); también están los derechos colectivos y difusos, en los que su titular ya no es el ser humano individual (ni tampoco regulan las relaciones entre los individuos y el Estado), sino que tratan de la protección de categorías o grupos de personas (familia, pueblo, nación, etnia, mujeres, homosexuales, menores, indígenas, etc.), y que no se encuadran ni en lo "público" ni en lo "privado", exclusivamente; Occidente hace hoy hincapié también en los derechos ambientales (consagrándoselos constitucionalmente, como ocurre en Brasil desde 1988, con el "derecho a un medio ambiente saludable"), en los derechos de la bioética (referentes en especial a la vida, la alimentación, la transgenia, la reproducción, el aborto y la eutanasia), y los derechos 
virtuales (para regular las situaciones derivadas del uso masivo de Internet y los mecanismos computacionales en general). Es importante subrayar que las cartas magnas de Venezuela, Bolivia (todo el Título II) y Ecuador los contemplan a todos; y en el caso de la boliviana, además de proclamar bienes nacionales inalienables a todos los recursos naturales, se prohíbe el uso de transgénicos, y se proclama el derecho al agua y a la alimentación (art. 16); de esa manera se concreta de forma básica pero transparente la preocupación de atender efectivamente a las necesidades de todos y cada uno de los seres humanos habitantes en su territorio.
La cartas magnas de Ecuador y Bolivia, asumiendo la satisfacción de las necesidades de cada individuo y de las comunidades como su finalidad máxima, declaran el "buen vivir" (sumak kawsay en la de Ecuador) y "vivir bien" (suma qamaña en la de Bolivia) como el objetivo mayor del Estado. Tal vivir bien, no puede desvincularse de una relación de preservación-regeneración de la naturaleza no humana, como lo veremos de inmediato. (Muy distinta, infelizmente, fue en gran parte y medida la actitud soviética en relación a la naturaleza no humana, considerada, como en el capitalismo, un recurso sin fin disponible para ser explotado sin cuidados).

\section{La perspectiva socioambiental}

Si en los años 60 y 70 en el fragor de la lucha (legal o guerrillera) algunos creímos que la ecología era asunto de bien nutridos que no tenían otra cosa que hacer, hoy descubrimos que la superación de la pobreza, creando las condiciones para que a cada humano se le exija socialmente según su capacidad y se le retribuya según su necesidad (para que se desarrolle como individuo universal) y la preservaciónregeneración de una naturaleza (humana y no humana) sana, son indisociables. El ser humano es parte de la naturaleza y (como desde siempre lo supieron las culturas indígenas), sin naturaleza no humana no hay ser humano. Por eso la perspectiva ecomunitarista es irrenunciablemente socioambiental, como lo atestiguan las tres normas éticas fundamentales en la que se basa; la tercera, en particular, nos obliga a velar por la salud de la naturaleza humana y no humana (aunque más no sea a partir del criterio de su salud para la producción).

\section{Democracia participativa, protagónica, intercultural y revocatoria: el poder popular}

El "socialismo real" pretendió en la revolución rusa unificar flui- damente los poderes constituyente y constituido a través de la entrega 
de "todo el poder a los sóviets" (supuestamente, representantes genuinos de la voluntad popular, que se expresaba en la mayoría constituida por proletarios, campesinos y soldados); pero con el enyesamiento del estalinismo, el poder constituido (en especial través del poder único del PCUS y de su líder máximo), fue desplazando de hecho al poder constituyente (que sería el pueblo congregado en las asambleas de los soviets, desde el nivel local, hasta el nivel nacional representando por el conjunto de los delegados que sesionaban en el consejo de los soviets de la URSS). El socialismo del siglo XXI arranca en América Latina con una reforma constitucional aprobada en 1999 que se presentó como una refundación de la nación venezolana (que incluso cambió el nombre del país que pasó de "República de Venezuela" a "República Bolivariana de Venezuela"), y se mantiene en actitud de debate acerca de esa Constitución (en especial en el referendo constitucional realizado el 02/12/2007 y el referendo sobre la enmienda que faculta la postulación del Presidente a reelecciones continuadas y sin límites, de febrero de 2009). Por otro lado, Bolivia también pretende reconstituir las bases mismas de la convivencia social a través de una reforma constitucional sometida a referendo en enero de 2009. Y lo propio hizo Ecuador (aunque sin tantas aspiraciones de cambios en la raíz misma del cuerpo político), en referendo celebrado en setiembre de 2008. Las experiencias en esos tres países muestran que lo que se pretende es que el poder constituido (en su expresión mayor que es el texto constitucional) sea sometido periódicamente a la evaluación del poder constituyente, sin suplantarlo nunca de forma definitiva-acabada. Por otro lado, tanto la Venezuela bolivariana como la nueva Bolivia y el nuevo Ecuador han instaurado el mecanismo revocatorio para las máximas autoridades ejecutivas locales (Alcaldes/Prefectos), estatales/ departamentales (Gobernadores) y nacionales (Presidente de la República), llevando a la práctica por lo menos en esas instancias ejecutivas la tesis que Marx sacó de la experiencia de la Comuna de París, de que las autoridades electas debían ser revocables por sus electores; claro que Marx agregaba "a cualquier momento", y las respectivas normas constitucionales venezolana y boliviana fijan límites a esa discrecionalidad (por ejemplo, que contra un electo y durante un mismo mandato, se puede proponer el referendo revocatorio sólo una vez).

Otro rasgo marcante de la fusión del poder constituyente (el pueblo, que nunca entrega toda su potestad) y el poder constituido, en el socialismo del siglo XXI que es abogada por Venezuela, Bolivia y Ecuador, es el gran impulso dado a la democracia directa ejercida desde y en cada comunidad local. Así, Venezuela ha creado los Consejos Comunales (que en 2008 ya 
eran más de 25 mil en todo el país, pudiendo haber varios en la misma barriada, según el tamaño de la misma y distribución local de la población en diversos núcleos poblacionales), como instancias donde los vecinos reunidos deciden lo que es prioritario para la comunidad local (una fábrica comunitaria, un centro deportivo, una plaza, etc.), y reciben directamente del Estado central (vía los Bancos Comunales creados por millares para ese fin) los recursos necesarios para ejecutar esos proyectos (cuya realización es fiscalizada desde el nivel local hasta el nacional, para garantizar el uso honesto y eficiente de los recursos). Por su parte, Ecuador se propone incentivar la democracia participativa en varios pasajes de la Constitución aprobada en Referendo en setiembre de 2008.

\section{La perspectiva intercultural}

Hoy resulta claro, especialmente en el caso de América Latina, que el socialismo del siglo XXI no podrá fundarse únicamente en fuentes occidentales, sino que deberá incorporar dialógicamente las contribuciones positivas oriundas de otras fuentes (particularmente las indígenas, negras y orientales). Las culturas indígena y negra han resistido a 500 años de conquista para legarnos su lúcida perspectiva cosmocéntrica socioambiental (que abordaremos en lo que sigue). El Oriente nos ilumina con su sabia reflexión-postura acerca del lugar del ser humano en el Cosmos y de la manera de habitarlo en nuestra condición de estrellas fugaces. Ello no significa que la unión de esas diversas tradiciones no tenga nudos de difícil manejo, que la filosofía ecomunitarista deberá enfrentar con franqueza (como es el caso, por ejemplo, del machismo que reina también en muchas culturas indígenas, negras y orientales).
La constitución ecuatoriana aprobada en setiembre de 2008 establece en su artículo 57 que se reconoce (entre otros, y repetiremos algunos conceptos antes citados) a las comunas, comunidades, pueblos y nacionalidades indígenas, los derechos de "mantener y fortalecer libremente su identidad, sentido de pertenencia, tradiciones ancestrales y formas de organización social", "conservar la propiedad imprescriptible de sus tierras comunitarias, que serán inalienables, inembargables e indivisibles (y exentas de impuestos)", "participar en el uso, usufructo, administración y conservación de los recursos naturales renovables que se hallen en sus tierras", "la consulta previa libre e informada, dentro de un plazo razonable, sobre planes y programas de prospección, explotación y comercialización de recursos no renovables que se encuentren en sus tierras... la consulta que deban realizar las autoridades competentes será obligatoria y 
oportuna", "conservar y desarrollar sus propias formas de convivencia y de organización social, y de generación y ejercicio de la autoridad, en sus territorios legalmente reconocidos y tierras comunitarias de posesión ancestral", "crear, desarrollar, aplicar y practicar su derecho propio o consuetudinario", "desarrollar, fortalecer y potenciar el sistema de educación intercultural bilingüe...desde la estimulación temprana hasta el nivel superior...", "construir y mantener organizaciones que los representen [a los pueblos indígenas]... [y] el Estado reconocerá y promoverá todas sus formas de expresión y organización", " participar a través de sus representantes en los organismos oficiales que determine la ley, en la definición de las políticas públicas que les conciernen, así como en el diseño y decisión de sus prioridades en los planes y proyectos del Estado", "ser consultados antes de la adopción de una medida legislativa que pueda afectar cualquiera de sus derechos colectivos", "mantener y desarrollar los contactos, las relaciones y la cooperación con otros pueblos, en particular los que estén divididos por fronteras internacionales", y remata pidiendo, como ya lo vimos, "que la dignidad y diversidad de sus culturas, tradiciones, historias y aspiraciones se reflejen en la educación pública y en los medios de comunicación; la creación de sus propios medios de comunicación y el acceso a los demás sin discriminación alguna".
A su vez la nueva Constitución de Bolivia (fruto de la ingente y a veces violenta movilización indígena-campesina-popular que Ilevó a Evo Morales al gobierno) va más allá aún que la ecuatoriana y la venezolana en la perspectiva intercultural cuando ya en su Preámbulo entre otras cosas se plantea el reto de "construir colectivamente el Estado Unitario Social de Derecho Plurinacional Comunitario..."; y en el artículo 1 proclama que "Bolivia se constituye en un Estado Unitario Social de Derecho Plurinacional Comunitario, libre, independiente, soberano, democrático, intercultural, descentralizado y con autonomías..." (los énfasis son míos). Expresión concreta de la interculturalidad es la proclamación en el artículo 5 de todas las lenguas indígenas (iy el texto constitucional enumera nada menos que treinta y seis! ) como lenguas co-oficiales del Estado, junto al castellano; más adelante se establece la obligación de que, junto al castellano, por lo menos una lengua indígena sea obligatoria, en función de la diversidad lingüística reinante, en cada región/localidad; y para reforzar esa exigencia, se establece la educación obligatoria bilingüe (también adaptada a la realidad lingüística de cada localidad). Los derechos concedidos a los "pueblos indígena originario campesinos" son (en especial en el capítulo IV del Título II) tanto o más extensos y precisos que los establecidos en la nueva Carta Magna de Ecuador y que hemos reseñado antes aquí. 


\section{La cuestión de los dirigentes y del partido dirigente}

La experiencia de los partidos únicos en el poder ha ido a la par de la eternización en el poder de ciertos líderes, acaudillados por un líder máximo. Tal fue el caso, entre otros, de Stalin en la URSS (desde por lo menos 1922 hasta su muerte en 1953), Mao Tse Tung en China (primero en el Partido y luego en el Estado desde 1949 hasta su muerte en 1976), y de Fidel Castro en Cuba (por lo menos desde 1959 hasta pasarle su cargo en la primera década del siglo XXI a su hermano Raúl, quien ya venía ejerciendo funciones de dirigente desde la guerrilla de la Sierra Maestra). Ahora bien, la enorme duración en el poder de los dos primeros dirigentes no evitó el actual retorno al capitalismo en esos dos países; retorno que en Rusia tiene carácter mafioso, y que en China cobra matices de superexplotación de trabajadores, incluso de niños, según los datos que nos Ilegan.

He oído decir a algunos cubanos que lo sucedido en el este europeo es en Cuba inevitable y/o que la alternativa es el modelo chino. Por mi parte constato, que si en Cuba se llegara a realizar tanto una como otra eventualidad, estaríamos dando muchos pasos hacia atrás en la búsqueda ecomunitarista del socialismo del siglo XXI. Al mismo tiempo, como la "política de todos" del ecomunitarismo pregona el ejercicio directo de la democracia siempre que posible, y la rotación de los dirigentes (para que nadie se eternice en el poder impidiendo la renovación de las ideas y las personas), me manifesté contra la iniciativa venezolana (que resultó vencedora en segunda instancia) de concederle al presidente de la República el derecho a la reelección continuada y por tiempo indefinido. Es de notar que el Partido Comunista de Cuba en su más reciente Congreso decidió que los máximos cargos serán ejercidos sólo por dos mandatos consecutivos (medida que al parecer no afectará a los actuales dirigentes, con Raúl a la cabeza).

En Cuba, tras la experiencia pluripartidaria de la lucha revolucionaria, desde el poder se gestó y permanece el Partido Comunista como partido único (no sólo de la revolución, sino del país). Desde fines de 2007 Venezuela construyó el Partido Socialista Unido de Venezuela (PSUV). Como toda la experiencia mundial, incluso la cubana, ha mostrado que el partido único es un serio freno a la libre, creativa y revolucionaria discusión de las ideas y a la adopción temprana de las mejoras necesarias (aclaro bien, para perfeccionar el intento poscapitalista, y no para retrotraerlo al capitalismo), ya he dicho que prefiero la experiencia pluralista del "movimiento" (como lo fue $y$ es en Uruguay, tanto el Movimiento de Liberación Nacional -Tupamaros_-, como el Frente 
Amplio, que desde 1971 agrupa desde personas oriundas de los partidos de derecha hasta trotskistas, pasando por democristianos, socialistas, comunistas y tupamaros). Tal forma plural puede combinarse mejor con esa nueva forma de acción política que son las redes; en una red (que a veces se crea para enfrentar un tema socioambiental preciso): a) hay reunión libre de personas a partir de una convergencia de valores y objetivos, b) cada integrante mantiene su autonomía de pensamiento-acción y es libre de entrar/salir a/de la red, c) cada integrante sólo hace parte de la red en la medida en que participa efectivamente de ella, d) cada integrante es co-responsable por la acción de la red, e) las decisiones no obedecen a un poder central sino que se toman de abajo hacia arriba y de forma descentralizada, f) la comunicación es horizontal y libre entre los integrantes de la red, y en los temas que ella así lo decida por consenso, también hacia afuera de la misma, g) la red admite sin restricciones la creación en su interior de sub-redes por tipo o modalidad de acción, h) la red no admite jefes fijos sino líderes provisorios-rotativos, i) la red se auto-reproduce, ampliándose o transformándose sin trabas; cada nudo, al establecer una conexión nueva, ayuda a esa conducta autopoiética, j) la red se orienta por el principio de solidaridad entre sus miembros y hacia afuera. Las redes demuestran hoy que la actividad "política" es mayor que la política partidaria, recobrando su sentido griego de 'organización de la ciudad-estado a manos del conjunto de los ciudadanos'. Esa acción en red tiene a veces a ONG como protagonistas, y otras veces a conjuntos semiorganizados. En esa última categoría vale recordar a los millones de ciudadanos que salieron a las calles de España para oponerse al envío de tropas a Iraq, que fueron los mismos que, autoconvocándose mediante sus teléfonos móviles, determinaron la inesperada derrota del Partido Popular del hasta entonces Presidente de Gobierno, José Maria Aznar, cuando, después de los atentados del 11 de marzo de 2004 en Madrid, juzgaron con lucidez, a pesar del profundo dolor del momento, que el envío de tropas determinado por Aznar contra la voluntad del $90 \%$ de los españoles (como lo habían revelado en su momento los sondeos) había sido la causa primera de la masacre.

\section{El poder popular y el Estado}

La entusiasmada y entusiasmante experiencia de los Consejos Comunales en Venezuela (alrededor de 25 mil, y el Presidente Chávez propone que se continúe en la agrupación territorial de los vecinos de varios de esos Consejos para constituir Comunas Socialistas, con potestades de gestión económica, política, cultural y militar), parece 
ser la piedra de toque que resuelva la difícil ecuación siguiente: ante la amenaza del cerco capitalista (y en especial del imperialismo norteamericano y europeo), un Estado fuerte en lo económico y lo militar es aún necesario en las primeras fases de construcción del socialismo del siglo XXI, pero, al mismo tiempo, esa fortaleza tendrá que ir descansando cada vez más y sin retorno en el poder popular ejercido de forma directa y protagónica. Así las Comunas Socialistas estarían Ilamadas en Venezuela a sustituir poco a poco a las instancias de gobierno estatal a nivel local, regional y nacional, en las esferas ejecutivas, legislativas y judiciales y en los planos económico, político, jurídico, cultural (en especial educativo y mediático) y militar; es obvio que hay que pensar en la coordinación y aprovechamiento de las diversas experiencias, que apunten padrones útiles en todas esas esferas y planos ( $y$, en especial en el de las normas y la educación, para que el espacio nacional no se fragmente de forma contraproducente para todas y cada una de ellas, en otras tantas comunidades locales mutuamente aisladas). En Bolivia y Ecuador, las aspiraciones de devolver el poder a las comunidades (en especial a las indígenas, tan importantes en la constitución demográfica-cultural de ambos países), puede seguir la vía venezolana de las Comunas (aprovechando las experiencias ancestrales del socialismo que supo ver y proyectar, aunque no libre de errores, Mariátegui). Cuba, a su vez, parece tener ante sí el mismo desafío que hundió a Gorbachov y a la URSS: perseverar en el socialismo devolviendo el poder a las comunidades organizadas en ejercicios de democracia directa y participativa; quizá la compañía de los tres países citados permita a Cuba resolver ese enigma, y evitar lo que sería un trágico regreso al capitalismo (aunque sea en la forma del neo-capitalismo de Estado adoptada por China).

\section{El socialismo del siglo $\mathrm{XXI}$ y las fuerzas armadas}

Diremos ahora sólo algunas breves palabras sobre este punto esencial, que merece un texto especial.

El socialismo del siglo XXI se estructura en base al poder ejercido por los ciudadanos directamente (como lo quiere hacer Venezuela a través de los Consejos Comunales y diversos Consejos de trabajadores, campesinos, mujeres, estudiantes, ancianos, etc.). Por definición es pacífico y pacificador. Pero nadie lo puede defender mejor que el propio pueblo armado; la experiencia de los países (supuestamente) socialistas de la Europa del siglo XX mostró que a pesar de la (aparente) formación ideológica prolongada, sus ejércitos permanecieron pasivos ante el desmantelamiento del sistema y la vuelta del capitalismo (quizá 
porque sus oficiales superiores se vieron beneficiados en el nuevo complejo industrial-militar, como ya lo eran en el anterior). Si se juzga que el hecho de que cada ciudadano guarde en casa su fusil, puede propiciar la violencia, ese arsenal (y otros equipos livianos y semipesados) debería guardarse en depósitos localizados en cada barrio, para que el pueblo pueda hacer uso de ellos rápidamente sin tener que acudir/depender a/de los siempre insondables e inseguros cuarteles.

Venezuela pretende incluir a medio plazo en sus Milicias (que fungen también como Reserva) un total de 2 millones de ciudadanos, de una población total de 27 millones de personas.

Hay que recordar que en Cuba, desde la revolución, hay una milicia popular, y además de la policía, los miembros de los Comités de Defensa de la Revolución (CDR) ejercen en cada barrio de forma rotativa, tareas de vigilancia policial, en especial rondas nocturnas. [Además, los vecinos del CDR hacen funciones de los funcionarios de la salud en las campañas de vacunación, de los de educación cuando interpeIan a la familia cuyos hijos faltan a la escuela, etc. Así se supera en parte por la acción comunitaria directa, la existencia de una policía y un ejército configurados como "cuerpos" estanques-separados.]. Es sabido cómo el movimiento indígena y campesino, tanto en Bolivia como en Ecuador, se han dotado de mecanismos de autodefensa que son un preanuncio de esas milicias y policías comunitarias que preconizamos para el socialismo del siglo XXI.

\section{La proyección internacional del socialismo del siglo XXI}

En estos últimos años la realidad latinoamericana está viendo nacer dos organismos que son capaces de prolongar los esfuerzos de construcción del socialismo del siglo XXI en la esfera internacional: el ALBA, la UNASUR y la CELAC. El ALBA (Alianza Bolivariana para los Pueblos de Nuestra América) cuando acaba 2012 está constituida por Cuba, Venezuela, Bolivia, Nicaragua, Honduras, Dominica, Ecuador, San Vicente y Granadinas, y Antigua y Barbuda. A su vez la CELAC (Comunidad de Estados La- tinoamericanos y Caribeños, creada en México en 2010) y UNASUR (Unión de Naciones Suramericanas, creada en Brasil en 2008) pretenden ser, respectivamente, instancias de integración entre Estados de Latinoamérica, el Caribe y América del Sur, sin la presencia de los EEUU (a diferencia de lo que sucede en la Organización de Estados Americanos, OEA), capaces, incluso, de implementar políticas comunes de defensa. Auspiciados por una y otra iniciativa germinan espacios de cooperación que pretenden escapar 
a la lógica capitalista, como lo son el Banco del Sur (fundamental para apoyar proyectos de economía solidaria, que podrían crecer enormemente si a él fueran transferidas las reservas monetarias latinoamericanas hoy depositadas y al servicio en/de EEUU y la Unión Europea) y
Telesur, esa gran alternativa informativa y cultural que tiene que llegar como TV abierta a la casa de todos los latinoamericanos, máxime desde que a fines de 2008 Venezuela y Uruguay lanzaron desde China el satélite de telecomunicaciones "Simón Bolívar".

\section{La educación para la libertad, el consenso y la preservación- regeneración de una naturaleza humana y no humana sana}

Ya he dicho que el proyecto poscapitalista puede verse tentado por una educación que Paulo Freire Ilamaría "bancaria" aunque revistiese la forma de un "catecismo rojo" (tanto más criticable que, como el catecismo católico, intenta imponer ciertas supuestas "verdades" en cabezas demasiado jóvenes como para entenderlas reflexivamente). Contra esa educación bancaria, defiendo a partir de Paulo Freire una educación ambiental problematizadora que sintetizo en el siguiente esquema sistémico-cualitativo:

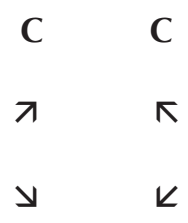

$\mathbf{R}$

Donde " $C$ " representa a cada uno de los sujetos en la interacción dialogal que hace parte del proceso de "conscientización" y " $R$ " repre- senta el referente, o sea, el objeto a propósito del cual los primeros están construyendo el conocimiento. Nótese que dicho referente no se limita a la clase de los objetos físicos, y puede ser también, por ejemplo, en tanto que "objeto" de conocimiento, el universo y tipo de las relaciones que unen-desunen a los sujetos en cuestión.

Dicho conocimiento, a propósito del referente, no será otra cosa sino la serie de los consensos a los cuales los sujetos dialogantes pueden llegar sobre la base del ejercicio de la libertad individual de convicción y postura, que se enriquece con el develamiento crítico progresivo del referente. ( $\mathrm{Y}$ cuando se dice "progresivo" no se entienda tal característica como siendo sinónimo de una acumulación sumatoria nocontradictoria, sino como proceso sometido a crisis de renovación, incluso de los fundamentos, como las descritas por Thomas Kuhn en The structure of scientific revolutions). 
Ahora bien, Freire situó la construcción del conocimiento al interior de la "praxis", que él definió como "la reflexión y acción de los hombres sobre el mundo para transformarlo" ${ }^{\prime 2}$. Por tanto, como la relación al referente no es solamente teórica, sino también prácticotransformadora, tenemos como resultado que no sólo las opiniones de los sujetos respecto del referente se transforman, sino que también cambia el propio referente.

Y, a su vez, la mudanza del referente no dejará de influenciar a los propios sujetos cognoscentes y a sus sucesores, al interior de una interacción de tipo "sistémica", aunque histórica. De ahí la doble flecha que parte tanto de los sujetos hacia el referente como del referente hacia los sujetos.

Ese proceso pedagógico es el de una incesante y mutua "conscientización" entre educador que sabe ser educando y educando que también educa, y que, a partir de Freire, caracterizo como la combinación indisociable (e infinita, para cada individuo y comunidad) entre desvelamiento crítico de las opre- siones vigentes en la realidad social y en la contaminación-devastación de la naturaleza no humana, y, simultáneamente, acción transformadora de esa realidad socioambiental rumbo al ecomunitarismo (o sea, un orden socioambiental sin opresores ni oprimidos y signado por la preservación-regeneración sana de la naturaleza en su conjunto).

La educación ambiental ecomunitarista muestra que debemos perseguir al mismo tiempo la realización de los individuos universales a partir de la aplicación del principio "de cada uno según su capacidad y a cada uno según su necesidad" y la preservaciónregeneración sana de la naturaleza humana y no humana (pues, como se ha dicho en diversas conferencias internacionales dedicadas al tema, y se recoge en la ley brasileña que estipula en 1999 la Política Nacional de Educación Ambiental, el "medio ambiente" debe ser entendido como algo que abarca, además de la naturaleza no humana, los aspectos económicos, sociales y culturales del contexto local o planetario que se focalice).

\section{Erótica libertaria y educación sexual}

Hemos sostenido que la vivencia de una erótica no represiva del placer compartido forma parte del desarrollo del individuo universal. Así, la educación problematizadora, formal y no formal, fundamentará su abordaje de la sexualidad en las tres normas fundamentales de la ética para pregonar y defender el derecho al libre y sano placer consensuado; en esa perspectiva deben ser objeto de crítica y superación 
la discriminación de la homosexualidad (de aquellas tres normas se apartan o se alejan por igual parejas hetero $u$ homosexuales), el machismo y la condena beata de la masturbación (en especial en la pubertad y adolescencia). Además del trabajo institucional que va desde la pre-escuela a la Universidad, podemos imaginar en el socialismo del siglo XXI innumerables espacios sociales de (re)educación sexual en la comunidad, la fábrica, la ONG, y el club social o deportivo.

\section{EI socialismo del siglo $X X I$ y las religiones}

Nuestra situación latinoamericana es diferente de la de las religiones de Estado de los países musulmanes. Desde nuestra situación constato que muchos hombres y mujeres se vuelcan a la lucha socialista desde sus convicciones religiosas (como se hizo patente desde los años 60 del siglo XX en los seguidores de la Teología de la Liberación). En esas circunstancias y como la urgencia actual es socioambiental y no teológica, defiendo y practico el ateísmo no militante de Marx en aras de la unión de todas las voluntades favorables al nuevo socialismo; más aún cuando la religión, retomando su raíz etimológica, se proponga "religar" a los seres humanos entre sí y al conjunto de éstos con la naturaleza no humana. Cuando ese nuevo socialismo esté consolidado, ya tendremos tiempo de debatir acerca de la alienación religiosa y de la superación de la religión. Esa tolerancia no quita que en los espacios específicos que se juzguen pertinentes, no debamos aclarar en qué consiste esa alienación y por qué su superación es fundamental (junto con la superación de la alienación en sus "dimensiones laicas", como dijo Marx), para que en el socialismo orientado al ecomunitarismo florezca hasta el límite de lo humanamente posible el individuo universal que realiza su existencia plena en relación de preservaciónregeneración con una naturaleza humana y no humana sana.

\section{Introducción a la cuestión de la comunicación en el socialismo del siglo XXI: Marx y la libertad de prensa}

Dijo el joven Karl Marx en 1849: "La función de la prensa es ser el can de guardia público, el denunciador incansable de los dirigentes, el ojo omnipresente, la boca omnipresente del espíritu del pueblo que guarda con celo su li- bertad". ${ }^{3}$ Sabemos cómo el llamado "socialismo real" europeo y también Cuba se alejaron totalmente de esa visión marxiana. La falta de libertad de prensa y aún la adulación de dirigentes supuestamente infalibles, crearon la llamada "langue de bois" 
(lengua de madera), tan unilateral y mentirosa que acabó por hacer que los pueblos del este europeo le diesen la espalda al supuesto socialismo, a cambio de un poco de libertad y pluralismo de ideas en los medios de comunicación. Desde ese punto de vista es admirable que Venezuela intente llevar adelante su proyecto de socialismo bolivariano respetando un debate que enriquece permanentemente esa búsqueda aunque y porque se traba con una derecha poderosísima en los mass media que no vacila incluso en promover a través de su prensa golpes de Estado y aliarse abiertamente al imperialismo yanqui con tal de detener ese proceso.

\section{El socialismo del siglo XXI en perspectiva ecomunitarista y los grandes medios de comunicación: una introducción}

Sobre este asunto habremos de detenernos en lo que sigue de este texto; asunto esencial, porque, sin renegar de la tesis marxista acerca de la importancia del factor económico, en las sociedades modernas se pudiera decir que el poder mediático es el primer poder, ya que sin su capacidad de formar opiniones y cabezas sumisas al capitalismo, las tragedias individuales y socioambientales del capitalismo se harían tan evidentes, que las grandes mayorías lo derribarían en corto plazo. Por ahora, me limito a avanzar la idea para este campo, de que en el socialismo del siglo XXI, los grandes medios audiovisuales $y$ escritos hoy en manos del Estado o de empresas capitalistas (nacio- nales y/o trasnacionales), deben ponerse en manos de las comunidades (por ejemplo de los Consejos Comunales y Comunas Socialistas en Venezuela); ello evitaría su uso privado por los capitalistas, y, por otro lado evitaría que se caiga en el paralizante "pensamiento único" de un Partido supuestamente socialista que monopoliza el poder; conste que la experiencia que propongo, es inédita cuando se trata de un país entero, aunque se pueden y deben aprovechar para ella las ricas contribuciones de millares de experiencias locales exitosas (concretizadas en TV y radios o periódicos comunitarios, como lo son desde hace décadas las radios de los mineros bolivianos).

\section{La cuestión de la objetividad: Fassano corregido por Apel}

En varias entregas semanales a lo largo de 2007 el periodista uruguayo Federico Fassano, dueño del diario La República, editado en Montevideo y con circulación na- cional, abordó el tema de la prensa bajo el título de "La cosa vostra", atacando los siguientes mitos ideológicos divulgados por los grandes medios: 1. La noticia es la que reina 
y gobierna; 2. La objetividad y la neutralidad son la base del sistema; 3. La privatización es la garantía contra la intromisión del Estado; 4. El cuarto poder es el poder autónomo de los medios; 5. La libertad de prensa es la religión de los medios;, 6. La opinión pública es el juez inapelable; 7. La participación es libre; 8. La publicidad iguala; 9. Somos esclavos en el trabajo, pero libres en el consumo y 10. La ausencia de prohibiciones resuelve el problema.

En su nota del 30 de noviembre de 2007 Fassano abordó el tema de lo que caracterizó como el mito de la objetividad y la neutralidad de la prensa. Allí cita a James Linen, editor del muy capitalista Time, quien sostuvo "que la objetividad total es tan imposible como indeseable. A menudo se nos dice que la función del periódico es sencillamente decir lo que ocurrió, qué hizo o qué dijo tal persona. Nada de opiniones ni de juicios, sólo hechos. Pero si un periódico o una revista de noticias sencillamente amontona todos los hechos en un artículo que puede imprimir, zacaso cumple con su responsabilidad hacia el lector? No lo creo. Me parece que esta obsesión con sólo los hechos puede conducir al absurdo". Por nuestra parte recordamos que, en las antípodas del positivismo, alguien dijo que no hay hechos, sólo interpretaciones. Fassano adopta esa visión cuando dice: "La falacia de la objetividad no resiste ningún test comparati- vo. Un mismo hecho noticioso en dos medios de comunicación con soportes ideológicos distintos produce dos impactos diferentes en el receptor [N.B.: Con John L. Austin, 1962, diríamos que vehiculan actos de lenguaje con distinta fuerza perlocucionaria). Porque no sólo las palabras, la textualidad, son las que conforman el mensaje. Su ubicación, su complemento gráfico, la tipografía empleada, la cantidad de tintas, la división del hecho, su titulación, su copete informativo, en fin, toda la gama técnicoprofesional de la presentación del acontecimiento, unido a lo que no se dice, a lo que se destaca, a lo que se minimiza, al colorido de la nota, todo influye en la producción del mensaje y su capacidad de convencer y hacerlo creíble, y reclutar al receptor para que acepte la carga ideológica latente del hecho que se le ofrece". Y más adelante aclara Fassano que (en un medio privado) no es el periodista quien decide si su texto se publica o no, pues esa decisión cabe a quienes manejan la línea editorial del mismo, la que, a su vez, se pauta por los intereses de sus dueños (parte o aliados de la oligarquía dominante); y señala que cuando un columnista se aparta de ellos, pronto será expulsado (si antes no renunció a su cargo). Por nuestra parte agregamos que esa falta de poder decisorio del periodista acerca de la publicación/ divulgación (o no) de su texto, lo equipara al trabajador alienado en el universo de la empresa capita- 
lista, de quien (como vimos antes) se espera que obedezca órdenes y no que argumente y decida. $Y$ concluía esa nota Fassano, diciendo: "Pero incluso la máscara de la objetividad tiene sus límites, como la democracia formal siempre los tuvo. Cuando suena el alerta roja general y el alerta se prende [N.B.: o sea, cuando peligran los intereses de la oligarquía], el sistema no duda en transformar la objetividad en propaganda abierta, en subjetivismo desenmascarado. Lo prueba la larga serie de regímenes de fuerza instaurados en América Latina en el siglo pasado, con el apoyo manifiesto, carente de todo disimulo, de los principales órganos de la gran prensa demoliberal del continente, partidaria de los gobiernos de opinión, hasta que el reclamo de las masas en las cuotas del excedente los llevó a consolidar el giro estratégico autocrático". En el siglo XXI tales palabras recibieron plena confirmación en la conducta de la gran prensa en los golpes de Estado consumados en Venezuela en 2002 y en Honduras en 2009, y el intentado en Bolivia en 2008; lo notable en esos casos (ahora la información a través de las antenas parabólicas e Internet nos permiten saberlo de inmediato) fue la coordinación de casi todos los grandes medios de comunicación privados de América Latina para divulgar a sus millones de receptores un sólo enfoque de los "hechos" y un sólo punto de vista, a saber, el de los golpistas; así desinforman sistemáticamente y "forman" literalmente la seudoopinión de millones de cabezas (cfr. Habermas 1962).

Por su parte Karl-Otto Apel aclaró (Apel 1985) que la visión cartesiana solipsista de la "objetividad" (que dependería del esfuerzo solitario de una mente por no dejarse influenciar en su percepción de "hechos" supuestamente independientes de ella) ha sido superada por una visión dialógica de la construcción del conocimiento; es ésta la que, como hemos mostrado (López Velasco 2009, Parte III), Paulo Freire (1970, Cap. II) defendió en su "pedagogía problematizadora" ya en los años 60 del siglo XX, donde la "objetividad" es el resultado de la crítica recíproca de los sujetos cognoscentes ( $y$, como tal, es variable, en función de la variación histórica sucesiva de esos resultados). Ello es totalmente coherente con la Cultura del Discurso Crítico a la que aludíamos antes.

Por su parte T. Van Dijk dice que el discurso periodístico puede estructurarse y analizarse en base a cuatro categorías principales: resumen (titular y encabezamiento), contexto e historia (antecedentes y hecho principal), consecuencias (hechos o acciones consiguientes y reacciones verbales), y comentarios finales (evaluación y predicción) ( $L a$ noticia como discurso. Comprensión, estructura y producción de la información, Ed. Paidós, Barcelona, 1990; ver Sylvia Fernández y Lour- 
des Molero, 2007, p. 3). Como ya dijimos, es evidente que el o los "hechos" en cuestión se delimitan a la luz de un ángulo de enfoque interpretativo específico. J.M. Adam presenta una tipología de los textos que los discrimina en (predominantemente) narrativos, descriptivos, dialogales, explicativos y argumentativos; la secuencia argumentativa se compondría de una "aserción de partida", una "aserción de pasaje" y una "aserción de llegada" (Les textes. Types et prototypes, Ed. Nathan, Paris, 1992; ver Fernández y Molero, 2007, p. 5). Como vemos, Adam toma aquí como base la estructura de los razonamientos, en el sentido aristotélico, y en especial la de los silogismos, compuestos por tres enunciados (que son, respectivamente, la premisa mayor, la menor y la conclusión). Los "razonamientos" compuestos por premisa(s) y conclusión, son la base de la Cultura del Discurso Crítico (CDC), resumida por Gouldner, como vimos anteriormente; nótese que si hemos bautizado casi-razonamientos causales (CRC) a las estructuras de las normas éticas, es porque, así como sucede con las premisas y conclusión de un razonamiento, el enunciado $E$ que sigue en un CRC al conectivo "porque" es pasible de discusión en términos de verdad o falsedad (lo que es determinante para la aceptación argumentada del obligativo que integra el CRC, situado antes de ese conectivo). A su vez Chilton y Shaffner sostienen que las funciones del discurso político son (y citamos literalmente el resumen de Fernández y Molero): "coerción" (los emisores actúan coercitivamente mediante el discurso al disponer la prioridad de los asuntos, seleccionar los temas de discusión y suponer realidades que los receptores se ven obligados a aceptar, aunque sea en forma provisional, para poder procesar el texto), "resistencia", "oposición" y "protesta" (cuando se consideran opositores al poder, los emisores intentan desplegar en un sentido contrario muchas de las estrategias discursivas utilizadas por los poderosos), "encubrimientos" (se utiliza para impedir que la gente reciba información o que algunas personas brinden información), "legitimación" y "deslegitimación" (entre las técnicas utilizadas se incluyen la proyección de un liderazgo carismático, el alarde sobre los propios logros, y la autopresentación positiva; su contraparte es la deslegitimación, en la que los otros, los enemigos, deben ser presentados negativamente, para lo cual se recurre a actos de habla como los de culpar, acusar, insultar, etc.) ("Discurso y políti$\mathrm{ca}^{\prime \prime}$, en T. Van Dijk, compilador, El discurso como interacción social, Ed. Gedisa, Barcelona, 2000, pp. 297-329; ver Fernández y Molero 2007, p. 6). Nos parece evidente que un comunicador revolucionario no puede escapar al ejercicio de la "coerción" tal como aquí se la define, pues es imposible abordar todos los temas todo el tiempo; mas, a partir de la ética (articulada en CRC) y de la Cultura del Discurso Crítico 
(CDC), creemos que: a) debe evitar la práctica del "encubrimiento", incluso cuando las informaciones presentadas como relevantes lo son por adversarios del socialismo del siglo $X X I, b)$ no debe buscar la "legitimación" de su posición ni la "deslegitimación" de la del oponente sino en el peso argumentativo (valor de verdad, por lo menos provisoria en aquel momento histórico) de sus razones discutibles como enunciados y/o como CRC, negándose a endiosar a líderes carismáticos (el final triste de los ejemplos de Stalin y Mao están a la vista), ni confundiendo la defensa de las conquistas revolucionarias con el ocultamiento acrítico de los errores, que se acompaña de una autopresentación hiper-positiva arrogante y acrítica, c) en consecuencia, no debe vacilar en ejercer, dentro de la revolución, la "protesta" e incluso la "resistencia" (cfr. Goudner en relación a la posición de los intelectuales respecto a los burócratas y dirigentes políticos indicados desde arriba), para que el socialismo del siglo $\mathrm{XXI}$, al corregir incesantemente sus carencias, se haga cada vez mejor y más fuerte, $y, d$ ) debe evitar caer en el insulto y la provocación, para defender y atacar posturas siempre en base al valor de verdad de sus argumentos; no olvidemos que en el socialismo del siglo XXI también queremos dejar atrás el argumento de autoridad, mediante la autoridad del mejor argumento.

En base a todo lo anterior hacemos las siguientes propuestas para orientar la acción del comunicador revolucionario.

\section{\begin{tabular}{c} 
Algunas propuestas genéricas ecomunitaristas para los \\
comunicadores en el socialismo del siglo XXI \\
\hline
\end{tabular}}

1. Luchar para realizar las tres normas éticas fundamentales, y en especial la primera, que nos exige realizar nuestra libertad individual de decisión (aunada con la segunda, que nos exige realizar aquella libertad en una dinámica de búsqueda consensual de la verdad y de las respuestas a dar a la pregunta "¿qué debo hacer?; sin olvidar nunca la tercera norma, de carácter socioambiental, que incluye la problemática ecológica, decisiva para el socialismo del siglo XXI pensado en perspectiva ecomunitarista; cfr. López Velasco 2009, Parte II).

2. Luchar por y ejercer (de conformidad con la primera norma) nuestra autonomía de investigación, juicio y opinión.

3. Definir explícitamente nuestro punto de vista como revolucionario, para que nadie se llame a engaño sobre nuestro ángulo de enfoque de la realidad. 
4. Practicar una comunicación que permita a cada uno (cada ciudadano) construir su libertad de decisión, en dinámica de búsquedas de consenso con los demás. Ello supone: a) fomentar la proliferación de los medios de comunicación comunitarios, donde el ciudadano sea, a la vez, el comunicador, y no un mero receptor pasivo del mensaje ajeno; sobre la ruina de la "opinión pública" a causa de esta asimetría comunicativa que se trasunta en la seudoconstrucción de una opinión privada. Ya se había pronunciado Habermas (1962) al denunciar a la prensa convertida en empresa, y al "receptor" pasivo cuya seudo-opinión es formada adialógicamente por los productos de aquella empresa; b) en los medios no comunitarios, darle la palabra al ciudadano para que ejerza su derecho a preguntar, criticar y proponer.

5. El comunicador revolucionario debe, en su medio de actuación, proponer y participar de debates con los adversarios de la revolución, pues no hay nada peor que "cocinarse en su propia salsa", sin escuchar (y por tanto reflexionar seriamente sobre ellos) los (seudo) argumentos de los adversarios; y nótese que muchas veces puede tratarse de argumentos legítimos que apunten a errores reales, que habrá que corregir lo más rápidamente posible.

6. El comunicador revolucionario deberá ser siempre crítico y autocrítico con el proceso revolucionario al que adhiere, so pena de dejar que ciertos errores se eternicen (y puedan dar al traste con ese proceso, como ocurrió en la URSS y demás países ex-socialistas); en esa tarea no deberá temer contrariar a los burócratas y jefes políticos con quienes su relación siempre será virtualmente tensionada (como bien lo destacó Gouldner).

6.1 Aun cuando la intención del adversario de la revolución sea perjudicarla, el revolucionario siempre sabrá distinguir esa intención y el error efectivo señalado, no cayendo en el error denunciado por el proverbio vietnamita que reza: "cuando un dedo apunta a la luna el idiota mira el dedo".

6.2 Para que el periodista de los medios públicos pueda desempeñar a cabalidad su papel críticoautocrítico, debe gozar de estabilidad laboral, como ya sucede en muchos países de América Latina con los docentes de las instituciones públicas de educación (en especial las universitarias, donde rige la libertad de cátedra).

7. Luchar para que todos los medios de comunicación estén en manos de los productores libremente asociados, a través de medios comunitarios (en manos de los vecinos de una localidad), y medios en manos de asociaciones de ciudadanos (sindicatos de trabajadores, gremios estudiantiles, universidades y cen- 
tros educativos, organizaciones ambientalistas y no gubernamentales, centros deportivos públicos, etc.). Mientras se lucha por esa realidad ecomunitarista los medios en mano del Estado (a nivel de gobierno central o gobiernos estadales o municipales) y sus comunicadores deben atenerse a la filosofía trazada en los seis puntos anteriores. En ese mismo ínterin los medios privados que subsistan (la nueva ley de medios argentina les permite ser a lo sumo el $33 \%$ de la totalidad de los medios) deben: a) incluir no menos de $70 \%$ de producción nacional (como ya lo estipula la ley venezolana de telecomunicaciones), b) plegarse a las cadenas determinadas por el poder público, c) ser jurídicamente responsables por las inverdades que difundan, d) abrir espacios obligatorios para los medios comunitarios y asociativos.
8. Luchar por la creación (y participación en ellos) de Consejos Comunales de Comunicación en los que los vecinos de un barrio discutan, sistematicen y elaboren la comunicación que sus pares desean divulgar, y la divulguen por todos los medios a su alcance (incluyendo Internet).

8.1 Promover y apoyar la creación de Consejos Comunicacionales de Empresa, de Cooperativa, de Centro Estudiantil, de Centro Deportivo, etc., en los que los trabajadores, campesinos, estudiantes, practicantes de deportes, que frecuentan cada uno de esos lugares, discutan, sistematicen y elaboren la comunicación que sus pares desean divulgar, y la divulguen por todos los medios (incluyendo Internet).

\section{La TV como herramienta comunicativa a partir del resumen de las Teorías de la Comunicación (presentado en Wikipedia)}

La teoría de Harry Pross (1971) situaría a la TV dentro de la comunicación terciaria, ya que el emisor y el receptor necesitan en este caso aparatos especiales para que se produzca el acto comunicativo (en la secundaria sólo el emisor los necesitaría, como ocurre con la máscara usada por un actor, y en la primaria el cuerpo y sus gestos bastan para que ocurra el acto comunicativo). La aproximación tecnocrática de la comunicación ubicaría a la TV como un ejemplo de la secuencia emisor-código- mensaje-medioreceptor; pero, como ya lo anticipamos y volveremos a decir, envolviendo esa secuencia técnica hay: a) un lenguaje cargado de contenido ético, con ideas que legitiman o critican y buscan superar al capitalismo, b) una relación social de capital que hace que los medios de comunicación (incluyendo a la TV) sean empresas capitalistas orientadas hacia la obtención de ganancia, o una relación social solidaria que busca en el socialismo del siglo XXI 
la realización universal de cada individuo, y que hace que los medios sean instrumentos de esa realización (aquí se sitúa la cuestión capital de la propiedad y gestión de los medios de comunicación, en especial de la $\mathrm{TV}$, en el socialismo del siglo XXI), $y, c)$ una distribución de roles que pueden ser de actividad del editorialista/emisor capitalista versus la pasividad del receptor/consumidor capitalista, o de actividad de ambos interlocutores en una vivencia socialista inspirada de la copedagogía freireana-ecomunitarista.

Es a la luz de esa contextualización que gana nuevas dimensiones la estructura analítica de Harold Lasswell que preguntaba "QUIÉN dice QUÉ a QUIÉN, través de cuál MEDIO Y CON CUÁlES EFECTOS", y el aserto crítico de Marshall Mc Luhan (1967) cuando afirmó: "El medio es el mensaje".

En primer lugar hay que recordar que Lasswell Ilamaba (1927, en Encyclopaedia of the Social Sciences) a reconocer la "ignorancia y estupidez de las... masas y a no sucumbir a los dogmatismos democráticos que estipulan que los hombres son los mejores jueces de sus propios intereses"; y a esa posición aunaba su constataciónconvicción-predicción-justificación de que cuando las elites no tienen la fuerza necesaria para imponer su voluntad a las masas, entonces usan "una técnica totalmente nueva de control, en gran parte por medio de la propaganda". Como se hace evidente, Lasswell acepta sin más la dominación de las elites capitalistas, por lo que el "QUIÉN dice" en su análisis es esa elite, el "QUÉ dice" es lo que conviene a la continuidad de su dominación, el MEDIO usado por ella son los medios de comunicación que PERTENECEN a esa elite, los EFECTOS buscados son la aceptación por el pueblo de la dominación de esa elite, y es el pueblo el "A QUIÉN", receptor pasivo, concebido como masa ignorante y estúpida, incapaz de decidir acerca de sus intereses $y$ destino, a quien va dirigido el mensaje propagandístico de la elite. Como se nota, la situación capitalista en materia comunicativa a través de los medios de comunicación masivos, refrendada por la posición de Lasswell, contraría punto a punto lo establecido por las dos primeras normas fundamentales de la ética; aquí tenemos otra manifestación de la comunicación asimétrica que criticamos en la empresa capitalista (y a la que daría cobertura una lectura ingenua de las "condiciones de felicidad" de los actos lingüísticos estipuladas por Austin).

A partir de las dos primeras normas fundamentales de la ética (y también desde la tercera) y en la óptica de la TV del socialismo del siglo XXI podemos rellenar la estructura de Lasswell como sigue. El quién dice, en la comunicación simétrica, son (idealmente) todos los seres humanos (por lo menos a partir de la edad en la que dominan el lenguaje); el qué dice, es el mensaje de amor, colaboración, 
coinformación y coaprendizaje, que distingue a la comunicación simétrica y solidaria al servicio del desarrollo universal de todos los individuos; el medio que usan es uno o varios de los de propiedad comunitaria o de propiedad social indirecta, que a todos pertenecen; el a quién dice, son todos los individuos capaces de comprender/ manejar el lenguaje; y los efectos perlocucionarios deseados abarcan tanto el aumento y/o perfeccionamiento del conocimiento (que según la segunda norma de la ética se edifica mediante consensos libres sucesivamente revisados), hasta la tranquilidad feliz del que se sabe amado/respetado/ ayudado/complementado por sus semejantes.

Ahora también podemos reinterpretar el aserto de Mc Luhan diciendo que el medio (en este caso el tipo/comportamiento de la TV socialista) debe ser ejemplo (y en ese sentido, mensaje) del tipo de comunicación que defendemos/ practicamos en aras de la realización universal de los individuos, hecha posible en la convivencia solidaria entre ellos y en el respetopreservación-regeneración de la naturaleza no humana sana (concebida, además de como "cuerpo inorgánico del ser humano", como quería el joven Marx, como Pacha Mama materna y englobante).

\section{¿La TV tiene efectos limitados o ilimitados?}

La Teoría Hipodérmica de la comunicación postuló que aquello buscado por el medio de comunicación entraba sin resistencia en el destinatario pasivo (como lo hace una aguja en nuestra piel); el individuo perdido en la masa sería objeto fácilmente manipulable por los medios de comunicación masivos, pues de ellos sacaría sus referencias para posicionarse como productor, consumidor, y (seudo)actor comunicativo, político y cultural. La Teoría Crítica, al desenmascarar la industria cultural capitalista, reforzaría esta visión, a pesar de ponerle los límites derivados de la capacidad que los individuos pueden tenerdesarrollar para superar en reflexión y postura de liberación, ese intento manipulador. Como ya lo han observado muchos, desde Adorno y Horkheimer, esa Teoría ha cuestionado en la industria cultural capitalista: a) la reducción de la producción estética a una mercancía más, realizada en serie, b) la reducción de los seres humanos al estado de masa, impidiendo el desarrollo de individuos emancipados, capaces de tomar decisiones racionales (con una razón ampliada, que incluya, además de la razón instrumental, a la razón práctica y al gozo estético), c) la sustitución de la posibilidad de autonomía y autoconciencia por la pereza del conformismo, la pasividad y el consumismo, y d) la promoción del escapismo a las tragedias capitalistas mediante el 
aislamiento y el consumismo y el hedonismo egoístas.

La Teoría de los Efectos Limitados intentó relativizar la importancia decisiva de los medios de comunicación masivosen la configuración de la visión de mundo que tienen los individuos, Ilamando la atención hacia las otras instancias sociales que participan en esa función, como lo son la familia, la iglesia, la escuela, etc. Recordemos que Althusser (1968) al tejer la crítica a los aparatos ideológicos del Estado capitalista pondrá a la escuela y no a los medios de comunicación masivos en el centro de su atención.

Mas, un nuevo dato que refuerza la teoría hipodérmica es el que deriva del descubrimiento de los mensajes subliminales, capaces de impactar el cerebro de un individuo más allá de su conciencia; así se sospechó de mensajes subliminales exhibidos en los cines, que llevarían a los espectadores a consumir a la salida algún tipo de refresco o alimento, y se denunció, en la campaña presidencial de George Bush contra Al Gore, el uso por parte del primero de un mensaje subliminal que destacaba el final "rats" (o sea, ratas, casualmente el mismo animal asociado por Hitler a la figura del judío) en la palabra "burocrats", usada para referirse a los supuestos seguidores y/o favorecidos de/ por Gore; ese mensaje fue en su momento retirado de la circulación.
También ha venido a reforzar la visión hipodérmica la percepción de la función des-sensibilizadora desempeñada por los medios de comunicación masivos(en especial por la TV), que consistiría en hacerle aceptar a los individuos situaciones traumatizantes impuestas por el capitalismo, suministrándole dosis continuas de esas mismas situaciones; en especial se ha hablado de la violencia que la TV banaliza día a día en obras de ficción, haciendo aceptable la violencia cotidiana propia al capitalismo; pero lo mismo podríamos decir de las relaciones patrón-empleado en la esfera productiva, o superior-subordinado, en esa esfera y otras, que esas mismas ficciones banalizan día a día, como si fueran naturales y eternas a/en la convivencia humana, cuando son parte del modo de vida capitalista; y así, traban en los individuos su disposición-capacidad de imaginar-querer un modo de vida que vaya más allá del capitalismo.

En relación a todo esto, creo que la TV socialista, apoyándose en las tres normas fundamentales de la ética: a) nunca debe proponerse operar a la manera hipodérmica, mucho menos con recursos subliminales, pues apuesta al desarrollo de individuos universales en permanente proceso de co-conscientización, y, b) nunca debe prestarse para estrategias des-sensibilizadoras, pues busca contribuir al máximo desarrollo y perfeccionamiento de la sensibilidad humana, en especial 
del amor solidario-cooperativo con los otros y de la salud de la naturaleza no humana. La TV socialista apostará siempre a la participación y co-construcción consciente- racional y sensible-amorosa de individuos universales solidarios entre si y respetuosos-preservadoresregeneradores de una naturaleza no humana sana.

\section{¿Quién elabora la agenda, y cuál agenda?}

La Teoría de la Agenda (mejor sería decir "agendamiento", para traducir la expresión inglesa Agenda Setting) ha estudiado-criticado la capacidad de los medios de comunicación masivos(incluyendo a la TV) para determinar la "pauta", o sea la lista de los asuntos que serán considerados relevantes por los individuos (desde el plano local hasta el planetario, adonde llegaban sólo las grandes multinacionales de la comunicación hasta la aparición de Telesur); ello va más allá de lo que se establece como "noticia", despreciando-ocultando todos los demás acontecimientos ocurridos en el mismo período temporal, para incluir también, por ejemplo, entre otros fenómenos, lo que será considerado "la" moda en el vestir, o en el peinarse, y aún "el" gusto musical y/o artístico del momento o la época.

Creemos que en la TV socialista del siglo XXI la agenda, en especial la noticiosa, debe ser elaborada por la comunidad (empezando por la local, para abarcar finalmente a la mundial); el comunicador participará en esa elaboración como un ciudadano-integrante más de su comunidad y de la familia humana (aunque ponga al servicio de tal elaboración sus capacidades técnicas especializadas, que, no obstante, nunca deben sobreponerse a, ni traicionar, la decisión comunitaria acerca de la agenda).

Dentro de esta concepción ecomunitarista de la agenda (en especial de la noticiosa) quedan incluidas las actividades de los actuales "guardianes de la puerta" (gatekeeper) y "hacedores de las noticias" (newsmaking), como ha bautizado la teoría de la comunicación a aquellos profesionales que dentro de la comunicación capitalista (en especial la TV, sea privada o seudopública), tienen la función de autorizar lo que será vehiculado en los medios de comunicación masivos, y por ende, lo que será considerado allí "noticia". Repetimos que en la TV socialista cabe a cada comunidad (desde la local a la planetaria) el ejercicio de tal función; ejercicio que deberá practicar con continua autocrítica, para mejorar-corregir sin cesar dicha elección, enderezando sus errores pasados.

En lo referente a las diversas 
expresiones estéticas, desde hace tiempo defendemos la idea de que el capitalismo nos da "ídolosmodelos" para amputarnos nuestra capacidad creativa. Por el contrario, una TV socialista promoverá la creatividad estética de cada individuo, incentivando el desarrollo de sus diversas vocaciones artísticas (por ejemplo en el campo de la poesía, la música, el teatro, el video, TV o cine, la vestimenta, el peinado, etc.), para contribuir a su desarrollo como individuo universal; y respetará su libertad cuando libremente decida aceptar a otro como modelo-guía de sus opciones y gustos.

\section{La TV pública y la TV privada}

El profesor Alejandro Montoya (de la Universitat de Valencia, España) en los apuntes de su disciplina acerca de la teoría de la radio y la TV (de 2011, anteriores al gobierno de Rajoy y disponibles en Internet), contrapone el modelo audiovisual europeo, supuestamente basado en un sistema público, al modelo de los EEUU basado en los medios de comunicación masivos privados. Mas hay que notar que el mismo Montoya observa que la ley española de medios aprobada en el gobierno de Rodríguez Zapatero permite que cualquier empresa de comunicación (radio o TV) compre a otra, desde que la suma de la audiencia de ambas no sobrepase el $27 \%$ de la audiencia total; ahí ya vemos como la vertiente privatista de la ley permite hipotéticamente que sólo cuatro grandes conglomerados empresariales controlen en España la totalidad de las radios y televisoras (repartiéndose el 25\% de la audiencia para cada uno).

Montoya dice que la TV privada ofrece lo que le conviene en función de sus ganancias, determinadas por el monto de la publicidad y la audiencia conseguidas, mientras que la televisión que él Ilama "pública" (y que por mi parte denominaré seudo-pública por los motivos que explicaré de inmediato) está condenada a ofrecer lo que su financiación le permite (constatando además que en España sus recursos financieros vienen disminuyendo desde que se sacó la publicidad a la TV estatal central, y ahora se pretende también sacársela a las televisoras autonómicas). Así contrapone Montoya el modelo de la TV privada anclado en el trípode audiencia-programación-publicidad, a la díada del modelo público programación-audiencia. Por nuestra parte creemos que la TV pública en España (y no sólo allí) es de hecho seudo-pública pues está controlada por intereses empresariales directos cuando tiene publicidad, o por intereses empresariales indirectamente expresados a través de los partidos políticos gobernantes que gestionan a la TV seudo-pública; en el caso de España, ello se expresa a nivel 
nacional en el dúo formado por el Partido Popular y el autodenominado Partido Socialista Obrero Español, que han demostrado en sus respectivas prácticas gubernamentales y a través de la TV seudo-pública que controlan mayoritariamente, que se acomodan a y disfrutan de los límites del capitalismo, sin plantearse jamás su superación; así se explica el reducidísimo espacio que tienen para detallar sus propuestas las formaciones y movimientos sociales asumidamente anticapitalistas; aunque esa TV tiene la astucia de oír de vez en cuando y por pocos segundos a alguno de tales actores sociales, para permitirse argumentar, ante eventuales cuestionamientos, que su práctica es "pluralista"; curioso pluralismo es ese en el que los defensores del capitalismo ocupan el 99\% de los espacios y tiempos, mientras que a los anticapitalistas se concede en cuentagotas el $1 \%$ restante.

La concepción socialista del siglo XXI, en materia televisiva, privilegia claramente los medios verdaderamente públicos (o sea de propiedad social directa o indirecta, comunitarios o estatales), y debe estar abundantemente financiada con los recursos públicos (que deben provenir tanto del Poder Popular como de los gobiernos central, estatal/provincial/departamental, y municipal, y que incluirán los impuestos específicos a los capitalistas cuando ello sea necesario), para permitirle un trabajo con gran alcance y calidad, que prescinda de la publicidad de empresas capitalistas (ya que la misma es intrínsecamente contradictoria con la promoción y el avance y perfeccionamiento del nuevo orden socialista). En ese contexto, y preparando el camino hacia la creación de muchas radios y televisoras comunitarias, nos hemos permitido sugerir repetidamente a los compañeros cubanos, que, para mejorar el debate acerca de la mejora de su socialismo, la Isla podría habilitar diversas radios y televisoras universitarias

Por otro lado el socialismo del siglo XXI acepta (al menos provisoriamente, mientras se camina rumbo al ecomunitarismo) a la TV privada; pero: a) la misma debe estar severamente regulada por la legislación pública atinente a su sistema de propiedad (prohibiendo, por ejemplo, la interferencia de multinacionales), alcance, estructura (definiendo los derechos de los trabajadores, por ejemplo, otorgándoles permanencia en el empleo), programación (imponiéndole pautas éticas de tratamiento de personas y temas, porcentajes de producción local y nacional obligatorios, contenidos educativos en determinados valores, adhesión a cadenas nacionales, etc.), y b) fijarle límites de expansión (como lo hizo Argentina, hasta el 33\% del total de estaciones de televisión) y de recursos financieros (evitando así una capitalización creciente indefinida). 
El profesor Montoya registraba cómo la TV más reciente (capitalista, agregamos nosotros) se llenó de reality shows, filmes norteamericanos, deportes, e informativos con mucha noticia en directo (siguiendo el eslogan: "Está ocurriendo y lo estás viendo") y poco trabajo de documentación-contextualización; y explica que ello se hace por la sencilla razón de que es más barato. Claro que se puede cuestionar la sencillez de tal explicación, haciendo notar por ejemplo, que si la producción cinematográfica de la India es más numerosa que la norteamericana y mucho más barata que ella, no por eso es la escogida para rellenar la parrilla de las televisoras de España (y de todo el mundo Ilamado "occidental", incluyendo a América Latina, con la excepción parcial de Cuba, y sospechamos que también en buena parte de los "tigres capitalistas" orientales, como lo son Japón, Taiwan y Corea del Sur); no es arriesgado afirmar que la elección de las producciones yanquis se inscribe en el contexto de la dependencia-subordinación de esos países a la gran locomotora capitalista que son los EEUU (desde el punto de vista económico, aún cuando debilitado en relación a China y la Unión Europea, y sobre todo, político-militar y cultural). A su vez, si la predominancia del directo en relación a la información contextualizada-historiada contribuye a ese bombardeo de saturación del noticiero capitalista que acaba por igualar todos los acontecimientos y anestesiar la capacidad de reacción de los televidentes, apabullados por la lluvia de datos que les cae encima diariamente (anestesia que es similar a la que aqueja al cerebro luego de un shock violento de emociones, tras el cual el individuo puede llegar a dormirse), a la luz de la nefasta experiencia informativa en el Ilamado "socialismo real del siglo XX", nos permitimos rescatar para la TV socialista la importancia del directo; en efecto en aquel autodenominado socialismo, los hechos eran muchas veces completamente ocultados o informados en diferido (como sucedió sucesivamente con el terrible accidente nuclear de Chernobil), negándole al ciudadano su efectiva participación en la comprensión, construcción y transformación de la realidad; la TV socialista, debe promover, por el contrario, esa incesante participación (que es una de las manifestaciones de la democracia directa, participativa y protagónica, defendida por el socialismo del siglo XXI y que es garantía de su continuidad y mejora indefinida).

La cuestión del deporte merecería un tratamiento demorado. Por ahora nos limitamos a subrayar, en primer lugar, que el enfoque capitalista del deporte (y en especial del fútbol, que es el preferido en España y América Latina) lo hace un sinónimo de negocio (en el cual 
los jugadores e incluso algunos clubes se venden y se compran como cualquier otra mercancía) y en el que se promueve el fanatismo de seguidores que creen subir al restricto círculo de los "ricos y famosos" identificándose con algún "ídolo" (hay que recordar que la etimología de esta palabra la hace sinónima de falso dios), y que se vengan-desahogan en actos violentos y racistas dentro y fuera de los estadios de la violencia cotidiana que les impone el capitalismo (a través de la inseguridad, del desempleo o el empleo inestable y siempre en peligro, las privaciones de un consumismo al que los impulsan pero para el cual no tienen dinero suficiente, la agresividad de un tránsito caótico, el temor relativo a la atención sanitaria pública deficiente o inexistente, la posibilidad de perder la vivienda a causa de una hipoteca imposible de pagar, y tantas otras miserias cotidianas que los achatan como individuos). Ahora bien, hay que registrar que la TV pública o seudo-pública no ha cesado de exhibir o ha retomado la disputa por la exhibición de los deportes con las televisoras privadas (así, la televisión estatal nacional española TVE mantuvo la exhibición de ciertos partidos de la selección española de fútbol, el estatal Canal 7 de Argentina retomó en el Gobierno de los Kirchner los derechos de exhibición del campeonato local de fútbol y de los partidos de su selección nacional, y el canal estatal venezolano TVES incluye en su pa- rrilla una abundante programación deportiva). En esa lucha o recuperación, creo que en la TV socialista hay que distanciarse del uso capitalista del deporte, y me parecen principios sanos los defendidos en 2012 por la Ministra uruguaya del Deporte, Liliam Kechichian, cuando, después de fotografiarse en las Olimpíadas de Londres al lado del futbolista uruguayo Edinson Cavani, "El Matador" (con actuación destacada en el Napoli de Italia), dijo (cf. "Il Ministro dello sport uruguaiano: 'Il Matador, esempio per i nostri giovani'", publicado en II Mattino de Nápoles, 10/11/2012, www. ilmattino.it) que Uruguay pretendía montar un sistema deportivo articulado que abarcase la práctica comunitaria, la práctica escolar (que se extiende hasta la Universidad) y el deporte de alto rendimiento; recordemos que los dos primeros niveles retoman, actualizándolos, el principio griego según el cual la educación del cuerpo (gimnasia) hace parte integrante e indisociable del proceso educativo y de la vida sana, y el principio que le siguió, reafirmándolo, y que reza "mente sana en cuerpo sano". Al mismo tiempo la Ministra dio indicaciones claras de los valores que debe promover el deporte (socialista, en nuestra propuesta) al destacar que Cavani (que, no lo olvidemos, hace parte del show deportivo capitalista) era un ejemplo para los jóvenes uruguayos por su conducta de trabajo, solidaria, y con sacrificio (y humilde, dijo también la Ministra, 
usando un adjetivo que también respaldamos si no se lo confunde con una actitud fatalista, ni de resignación, ni de menosprecio de y renuncia a las propias capacidades para contribuir creativamente con el colectivo).

A su vez la cuestión del auge del reality show también trasciende la explicación por el bajo costo, esgrimida por Montoya. Aquí la psicología debería investigar los por qué de esa adhesión al voyeurismo recíproco que caracteriza a ese tipo de programa; por nuestra parte sólo nos permitiremos avanzar alguna hipótesis en el apartado que sigue, donde nos preguntamos sobre el por qué de la importancia asignada a la aparición en la TV. Pero antes, notemos que a los rubros de programación reseñados por Montoya como dominantes en la TV capitalista más reciente, hay que agregar las tertulias con invitados, acerca de temas de actualidad (en especial en el área política, social y económica), abundantes en la TV española y en algunas de A. Latina (en especial en las TV cableadas). Lo notorio en estas tertulias es que todos los participantes defienden alternativas capitalistas (a veces diferenciadas sólo como matices); y en el caso español lo siguen haciendo con toda desfachatez después de que sus previsiones fueron repetidamente desmentidas por la realidad (por ejemplo, cuando auguraban que España nunca caería hasta una situación de crisis comparable a la de Grecia). Como ya lo anunciamos, en la TV socialista las tertulias deben incluir espacios de debate intrarevolucionario (para que nos aclaremos recíprocamente en la búsqueda de lo que es mejor para el presente $y$ futuro del socialismo del siglo XXI en perspectiva ecomunitarista), $y$ también de debate con voceros de la oposición (de derecha), para que el público (que también debe poder participar preguntando y opinando) se vaya haciendo una idea cada vez más elaborada acerca del tema en discusión.

\section{¿Por qué la TV es tan importante?}

Podríamos explicar el voyeurismo recíproco al que acabamos de referirnos por el hecho de que en la cultura capitalista animada por los EEUU se ha hecho canónica la división entre "ganadores" y "perdedores" (o "fracasados", loser) en la vida, y porque son personajes reiterativos en la TV los primeros, a saber los "ricos y famosos" (si es posible también "bonitos", o, por lo menos "elegantes"). Entonces, la obsesión por querer aparecer en la TV por parte de ciudadanos anónimos (incluso en programas donde desvelan aspectos sórdidos de sus vidas), podría vehicular la intención de igualarse a los integrantes de aquel grupo de los "ganadores", e incluso la pretensión de integrar- 
se (aunque sea de forma efímera) a él; (nótese que esa integración aparentemente efímera a veces no lo es tanto, pues puede ocurrir que alguno de los participantes del Gran Hermano, por ejemplo, después de su pasaje en dicho reality show, sea contratado como modelo, modelo publicitario, o jurado de otros programas, subiendo así en su estatus económico y de "visibilidad social", pues continúa frecuentando la TV, de forma continua o discontinua).

También dice Montoya que se ha cuestionado la idea de que la pantalla de la TV sea el espejo de la realidad, catalogándosela más bien como un cuadro opaco. Es evidente que tal caracterización se justifica por las diversas artimañas de manipulación, distorsión, ocultamiento y selección intencionada que la TV practica al ser instrumento del capitalismo (artimañas generadas en las opciones de uno o más empresarios capitalistas y/o de sus subordinados); mas creo que no por ello debemos renunciar a la posibilidad de pulir ese cuadro, para hacerlo más fiel a la realidad que se construyereconstruye comunitariamente sin cesar en el socialismo del siglo XXI; sin dejar de percibir que la realidad vehiculada-construida en la TV socialista nunca será "toda" "Ia" realidad, en la medida en que esa construcción-reconstrucción incesantemente inacabada acompañará a la humanidad hasta su extinción, y también en la medida en que en el tiempo limitado de la TV (aunque éste sea de 24 horas diarias), jamás habrá lugar para todos los acontecimientos que ocurren simultáneamente en una jornada, y entre los cuales los gestores de la TV tendrán que conformarse con seleccionar algunos, silenciando a todos los otros; como alguien dijo, "elegir (algo) es renunciar (a todo lo demás)".

A su vez, Alejandro Rozitchner (2008) también usó la imagen del espejo, para decir (quizá aludiendo a "Alicia en el país de las maravillas") que la importancia que se le da al hecho de aparecer en la TV se debe a que esa es una forma de pasar al otro lado del espejo, vivenciando una suerte de trascendencia que es la propia ( y reverenciada) de los muertos.

Por mi parte creo que en la TV socialista esa aparición debe ser una manifestación más de la vida abundante de individuos que se constituyen progresivamente como individuos universales; y que saben que esa TV es una manifestación más del "vivir viviendo" (como dijo el Presidente Chávez), que complementa y se articula armónicamente con sus otras vivencias socialistas, sean ellas actividades económicas, políticas, educativas, eróticas, comunicativas y/o estéticas. 
Correcciones en Venezuela

Cuando inmediatamente después de su nueva reelección ocurrida el 7 de octubre de 2012 el Presidente Chávez Ilamó a hacer una profunda autocrítica para encarar la nueva etapa de profundización de la revolución bolivariana que se extendería hasta 2019, también incluyó en tal demanda al área de la comunicación, observando que no existía una verdadero sistema nacional de medios públicos (pues cada uno de ellos haría vida en separado), y que algunos comunicadores le hacían eco exagerado (so pretexto de criticarlos) a seudo-personajes de la derecha cuya audiencia era mínima. Posteriormente y al calor del llamado del Presidente, el nuevo Ministro de la Comunicación, el periodista Ernesto Villegas, convocó el Foro "Comunicación y Revolución", en cuya primera sesión detectamos los siguientes aspectos interesantes: a) se cuestionó a los comunicadores que gastaban mucho tiempo en tratar de aclarar cosas que el pueblo ya tenía claras desde el golpe contra Chávez de abril de 2002, cuando las multitudes burlaron el cerco mediático de la derecha para exigir la vuelta del presidente democráticamente electo, b) se exigió que los medios fueran hasta los barrios, para oír de las comunidades sus opiniones acerca del tipo de medios y de programación que les parecen más adecuados, c) se criticó el hecho de que a veces las televisoras comunitarias Ilenasen su parrilla con programas sacados de los canales estatales (agrego yo, o por falta de financiación, y en ese caso tendrán que desembolsar los recursos necesarios el Poder Popular y los poderes públicos central, estatal y municipal, o por falta de creatividad-propuestas, y en ese caso habría que reforzar los mecanismos de formación comunicativa de las comunidades y sus líderes) y d) se criticó el poco uso revolucionario que los medios públicos hacen de recursos comunicativos caros al pueblo, como lo son las telenovelas y los ritmos musicales más practicados por los jóvenes.

\section{El perrito de Obama}

En el último tópico recién abordado aludíamos a aspectos emotivos y estéticos que no pueden ser descuidados en la TV socialista; y vale la pena recordar con qué eficacia y abundancia los usa la TV capitalista; un pequeño ejemplo de ello es la imagen del Presidente de los EEUU jugando con sus hijos o su perro, ampliamente divulgada por las televisoras privadas dominantes en América Latina, al tiempo que las mismas jamás divulgan imágenes parecidas de Chávez, o Evo, o Correa, por el sencillo motivo de que esas imágenes generan un sentimiento de "simpatía-empatía" hacia/con el protagonista, que es- 
tas emisoras nunca quieren que se dirija a los tres presidentes latinoamericanos mencionados (contra los que libran todos los días una batalla sin cuartel). Cabrá a la TV socialista no prestarse a ese juego y, ipor qué no?, pagar con la misma moneda, divulgando imágenes poco simpáticas de los personeros del imperio y las oligarquías seudo-criollas.

\section{Innovaciones técnicas}

El programa de Pérez Pirela "Cayendo y corriendo" exhibido diariamente en la estatal Venezolana de Televisión (VTV) impresionó en sus primeros tiempos por la creatividad en los ángulos de enfoque y movimientos de cámara, y en la división de la pantalla para mostrar varios ángulos simultáneamente. Creemos que innovaciones técnicas como esa deben ser permanentemente buscadas y usadas en la TV socialista, para practicar una comunicación que sea lo menos rutinaria posible. Si algo lamentamos es que después de establecido el programa, su autor (¿o la producción?) optó por reducir el uso de esas variantes (aunque el presentador siguió moviéndose en la escena, evitando permanecer estático ante la cámara). Dicho esto, creemos no obstante que dicho presentador queda incluido entre aquellos que han sido correctamente criticados por centrar demasiado su labor en los decires de voceros poco oídos de la oposición (en vez, agrego yo, de profundizar en las propuestas- alternativas revolucionarias, interactuando con el pueblo que trata de inventarlas e implementarlas diariamente).

¿El ancla debe opinar?

Durante mucho tiempo las presentadoras y los presentadores de los informativos televisados dieron las noticias sin mayor expresividad y sin ninguna opinión agregada; así se pretendía reforzar el mito de la "objetividad" y "neutralidad" de tales informaciones y de la empresa que los vehiculaba. Sin embargo hace unos años muchos informativistas de TV (en especial de las grandes empresas privadas en A. Latina) comenzaron a agregar a algunas noticias una observación supuestamente personal, a veces en tono francamente valorativo (como en el caso del presentador brasileño que popularizó la muletilla "qué vergüenza!", con la que concluía alguna noticia de algún hecho que él consideraba reprobable). Ante este cambio de comportamiento cabe observar, en primer lugar, que tales comentarios jamás son contrarios a los intereses de la empresa propietaria de la TV y a aquellos que ella defiende (por ejemplo, de un determinado gobierno, o del capital, o del Gobierno de los EEUU); en segundo lugar, que esta función de opinión requiere un estudio previo responsable del tema en cuestión por parte del informativista, so pena de decir inverdades o trivialidades; $y$, en tercer lugar, que si ella es defendible en la 
TV socialista en la medida en que el informativista es un ciudadano más, con iguales derechos y deberes comunicativos-opinativos que cualquier otro, cuando ejerza la función de opinión el informativista deberá siempre informar al público acerca del conocimiento previo en el que la basa, y acerca de los límites del mismo.

\section{A modo de brevísima conclusión provisoria}

Como lo decíamos en la introducción de este trabajo, la temática aquí abordada gana importancia diariamente y de forma creciente. En estas líneas no hemos pretendido dar sino un pequeño paso en una gigantesca marcha, pero, como dice el proverbio chino, toda larga caminata comienza con un paso. Aguardaremos con mucho interés y gratitud las críticas, observaciones y trabajos futuros que superen las limitaciones del nuestro, y lo corrijan, profundicen y amplíen, como debe ser.

\section{Bibliografía}

- Althusser, L. (1969). Idéologie et appareils idéologiques d'État, La Pensée, París.

- Appel, K. O. (1973). Transformation der Philosophie, Suhrkamp, Frankfurt. La transformación de la filosofía, Taurus, Madrid, 1985.

- Austin, J. L. (1962). How to do things with words, Claendon Press, Londres. Quando dizer é fazer, Artes

- Constitución Política del Estado, Bolivia, 2009, en Internet.

- Constitución de la República del Ecuador, septiembre 2008, en Internet.

- Diario La Tercera, Santiago de Chile, 21/09/2008, p. 21 (Los intelectuales más influyentes en América Latina).

- Freire, Paulo. Pedagogia do Oprimido, Ed. Paz e Terra, Río de Janeiro, 1970.

- Freud, S. (1968). Obras completas, Biblioteca Nueva, Madrid.

- Habermas, J (1962). Strukturwandel der Öffentlichkeit, Neuwied, Frankfurt.

- Harnecker, Marta. Gobiernos comunitarios. Transformando el Estado desde abajo: Experiencia en la construcción del poder popular en el Municipio Libertador (Estado de Carabobo, Venezuela), Ed. Monte Ávila, Caracas, 2007. 
- Kononenko, Vasili. "Ricos y pobres en Rusia", en La República, Montevideo, Uruguay, 21/10/2005.

- Kuhn, Thomas. The structure of scientific revolutions, Univ. of Chicago, Chicago, 1962.

- Lasswell, Harold. Propaganda in the World War, 1927.

- López Velasco, Sírio. Ética para mis hijos y no iniciados, Ed. Anthropos, Barcelona, España, 2003.

- López Velasco, S. Fundamentos lógico-lingüísticos da ética argumentativa, Nova Harmonia, S. Leopoldo, 2003.

- López Velasco, S. Ética para o século XXI. Rumo ao ecomunitarismo, Ed. Unisinos, S. Leopoldo, 2003.

- López Velasco, Sirio. Ética ecomunitarista. Ética para el socialismo del siglo XXI, Ed. UASLP, México, 2009.

- López Velasco, Sirio. Ecomunitarismo, socialismo del siglo XXI e interculturalidad, Ed. del Ministerio para el PP para la Cultura, San Juan de los Morros (Edo. Guárico), Venezuela, 2009b y Ed. FURG, Rio Grande, Brasil, 2009.

- López Velasco, Sirio. Ucronía, Ed. FURG, Rio Grande, Brasil, 2010.

- López Velasco, Sirio, El socialismo del siglo XXI en perspectiva ecomunitarista, Ed. UASLP, México, 2010

- López Velasco, Sirio, Ideias para o socialismo do século XXI com visão ecomunitarista, Ed. FURG, Rio Grande, 2012,

- Marx, K. (1844). Ökonomische-Philosophische Manuskripte. Manuscritos de economía e filosofía, Martin Claret, S. Paulo, 204.

- Marx, Karl. Liberdade de imprensa (1849), Ed. L\&PM, Porto Alegre, 2007.

- Marx, Karl. "Crítica al programa de Gotha" (1875), en C. Marx \& F. Engels, "Obras Escogidas", vol. III, Ed. Progreso, Moscú, 1974.

- Mc Luhan, Marshall. The Medium is the Message, Ed. Random House, N. York, 1967.

- Montoya, Alejandro. Apuntes Teoría de la Radio y la TV, 2011, en http:// comunicaudio.jimdo.com/descarga-apuntes-2\%C2\%BA/teor\%C3\%ADasde-la-radio-y-televisi\%C3\%B3n/

- Pross, Harry. Medienforschung. Ed. Carl Habel, Darmstadt, 1971. 
- Rozitchner, Alejandro. Teoría de la TV, 2008, en www. youtube.com/ watch? $=X P 2 N / n h \_p j Y$

- Saviani, D. (1983). Escola e democracia, Cortez, S. Paulo.

- Wikipedia. Teorías de la comunicación; teorías de la TV

- Wolkmer, Antonio C. "Etapas de la historicidad de los derechos Del hombre" en REDHES, n², Ed. UASLP-UAA, México, 2009.

NOTAS

1 "Etapas de la historicidad de los Derechos del Hombre" en Revista de Derechos Humanos y Estudios Sociales, No. 2, UASLP-UAA, México, 2009.

2 Freire, Paulo, Pedagogia do Oprimido, Ed. Paz e Terra, Río de Janeiro, 1970, Cap. I.
3 Marx, Karl, "El papel de la prensa como crítica de los funcionarios gubernamentales", escrito en su autodefensa en juicio de 1849 por un supuesto delito de prensa; en Karl Marx: Liberdade de imprensa, Ed. L\&PM, Porto Alegre, 2007. 